$\begin{aligned} & \text { Науковий вісник НлтУ України } \\ & \text { Scientific Bulletin of UNFU } \\ & \text { https://nv.nltu.edu.ua }\end{aligned}$
$\begin{aligned} & \text { https://doi.org/10.36930/40310508 } \\ & \text { Article received 04.10.2021 p. } \\ & \text { Article accepted 25.11.2021 p. }\end{aligned}$
UDC 630.[228+524+548]:633.872.1 1994-7836 (print)
ISSN 2519-2477 (online)

С. І. Мусієнко, М. Г. Румянцев, О. М. Тарнопільська, В. А. Лук'янець, В. В. Бондаренко

Український ордена "Знак пошани" науково-дослідний інститут лісового господарства і агролісомеліорації ім. Г. М. Висоцького, м. Харків, Україна

\title{
СТАН І ПРОДУКТИВНІСТЬ ДУБОВИХ НАСАДЖЕНЬ ЛІСОСТЕПУ ХАРКІВЩИНИ
}

За матеріалами повидільної бази даних (станом на 2017 р.) проаналізовано розподіл вкритих лісовою рослинністю ділянок лісостепової частини Харківської області (на прикладі ДП "Жовтневе ЛГ") за панівними породами, а також дубових насаджень за походженням, типами лісу, групами віку, класами бонітету та повнотами. Наведено динаміку основних таксаційних показників дубових насаджень за їхнім походженням. Визначено показники використання лісорослинного потенціалу дубовими насадженнями природного і штучного походження в найпоширенішому типі лісу - свіжій кленово-липовій діброві. Результати проведених досліджень свідчать, що в лісовому фонді ДП "Жовтневе ЛГ" найпоширенішими $є$ дубові лісостани, частка яких становить 74,8 \% (33,9 тис. га) від загальної площі вкритих лісовою рослинністю ділянок. Виявлено, що серед дубових лісів за площею істотно переважають природні лісостани $(62,4$ \%) II класу бонітету та штучні насадження I і вище класу бонітету (майже $50 \%$ ) і мають повноту 0,7 та 0,8 , частка яких становить 62 та 84 \% відповідно. Проте в регіоні досліджень переважають порівняно низькопродуктивні порослеві дубняки. Вікова структура дубових лісів є розбалансованою із переважанням за площею середньовікових насаджень, частка яких сягає 78 \% - у насадженнях природного походження та $86 \%$ - у насадженнях штучного походження. Для насаджень природного походження характерні вищі таксаційні показники (середні вік, діаметр, висота, повнота) порівняно зі штучними. Показники ефективності використання ними лісорослинного потенціалу є невисокими та змінюються у віці 80-100 років в межах 60-62 \% у насадженнях природного походження та 67-74 \% - у насадженнях штучного походження. Надано пропозиції щодо здійснення відповідних лісогосподарських заходів для оптимізації вікової структури, підвищення продуктивності дубових насаджень та посилення виконання ними важливих еколого-захисних функцій.

Ключові слова: лісорослинний потенціал; модальні насадження; бонітет; тип лісу.

\section{Вступ / Introduction}

Пріоритетним завданням лісового господарства $\epsilon$ раціональне й ефективне використання земель лісового фонду для отримання максимальної кількості деревних ресурсів з одиниці площі з одночасним збереженням й відтворенням багатогранних екологічних функцій лісів.

Дані обліку лісів України [1] та результати чисельних вітчизняних досліджень $[2,3,4,5,6,7,10,11,12$, $13,14]$ свідчать про можливі резерви щодо підвищення продуктивності лісів країни, зокрема й у межах Лісостепу Харківщини. Показник використання лісорослинного потенціалу (ВЛП) - співвідношення фактичної продуктивності насадження до потенційної, є важливим для ведення лісового господарства, адже врахування особливостей лісорослинних умов дасть змогу отриму- вати максимальну економічну вигоду без зниження ефективності виконання лісами важливих еколого-захисних функцій $[2,5,7,8,10,11,12,13,14]$. Успішна реалізація цих завдань можлива за умови планування всіх лісівничих заходів на типологічній основі.

У період реформування галузі виникла потреба у здійсненні комплексних досліджень сучасного стану та продуктивності дубових насаджень у різних регіонах країни, зокрема й у межах Лісостепу Харківщини, для розроблення ефективних лісогосподарських заходів, спрямованих на підвищення продуктивності дубових лісів регіону та посилення виконання ними важливих еколого-захисних функцій.

Об'єкт дослідження - дубові насадження ДП "Жовтневе ЛГ".

Інформація про авторів:

Мусієнко Сергій Іванович, канд. с.-г. наук, ст. наук. співробітник, лабораторія лісівництва. Email: musienkosergij_les@ukr.net; https://orcid.org/0000-0002-6581-2670

Румянцев Максим Григорович, канд. с.-г. наук, ст. наук. співробітник, лабораторія лісових культур та агролісомеліорації. Email: maxrum-89@ukr.net; https://orcid.org/0000-0002-2245-2441

Тарнопільська Оксана Михайлівна, канд. с.-г. наук, ст. наук. співробітник, лабораторія лісівництва. Email: tarnoks@ukr.net; https://orcid.org/0000-0002-4810-8892

Лук'янець Володимир Антонович, ст. наук. співробітник, лабораторія лісівництва. Email: lukyanetc@uriffm.org.ua; https://orcid.org/0000-0002-3427-4240

Бондаренко Віра Володимирівна, мол. нак. співробіник, лабораторія лісівництва. Email: Ispg@ukr.net; https://orcid.org/0000-0001-8187-5519

Цитування за ДСту: Мусієнко С. І., Румянцев М. Г., Тарнопільська О. М., Лук'янець В. А., Бондаренко В. В. Стан і продуктивність дубових насаджень Лісостепу Харківщини. Науковий вісник НЛтУ України. 2021, т. 31, № 5. С. 54-59.

Citation APA: Musienko, S. I., Rumiantsev, M. N., Tarnopilska, O. M., Lukyanets, V. A., \& Bondarenko, V. V. (2021). Sondition and productivity of oak plantations in the Forest-steppe of Kharkiv region. Scientific Bulletin of UNFU, 31(5), 54-59. https://doi.org/10.36930/40310508 
Предмет дослідження - методи і засоби визначення лісівничо-таксаційних показників і продуктивності дубових насаджень ДП "Жовтневе ЛГ".

Мета роботи - оцінити сучасний стан дубових насаджень Лісостепу Харківщини (на прикладі ДП "Жовтневе ЛГ"), а також їхню продуктивність та використання ними лісорослинного потенціалу.

Для досягнення зазначеної мети визначено такі основні завдання дослідження: оцінити сучасний стан і продуктивність дубових насаджень ДП "Жовтневе ЛГ"; визначити показники використання ними лісорослинного потенціалу.

Наукова новизна отриманих результатів дослідження - вперше проаналізовано сучасний стан дубових насаджень ДП "Жовтневе ЛГ" та визначено показники використання ними лісорослинного потенціалу для розроблення ефективних лісогосподарських заходів, спрямованих на підвищення продуктивності дубових лісів регіону та посилення виконання ними важливих еколого-захисних функцій.

Практична значущість результатів дослідження $\epsilon$ основою для планування лісогосподарських заходів, спрямованих на підвищення продуктивності дубових лісів регіону та посилення виконання ними важливих еколого-захисних функцій.

Аналіз останніх досліджень та публікацій. Нині на великих площах лісорослинний потенціал насаджень використовується недостатньо. Так, результати досліджень В. П. Ткача та ін. [11] із кількісного оцінювання використання лісорослинного потенціалу насадженнями основних лісотвірних порід України (сосни звичайної та дуба звичайного) за природними зонами та типами лісу свідчать, що в середньому лісорослинний потенціал земель використовується насадженнями на 50-75 \%. Середньозважений показник ВЛП сосняками Полісся становить 68-76 \%, Правобережного та Лівобережного Лісостепу - 70-78\% та $68-73 \%$ відповідно, Степу - 54-78 \%, дубовими насадженнями Правобережного та Лівобережного Лісостепу - 71-75 \% та 63-71\% відповідно, Степу - 65-75 \%. Ми розробили таблиці продуктивності модальних та еталонних (високопродуктивних) соснових і дубових деревостанів.

Завдання підвищення продуктивності лісів для лісів, вилучених із режиму головного користування, як і для експлуатаційних лісів, $є$ основним, якщо воно не суперечить головній меті ведення в них лісогосподарської діяльності (підвищення стійкості та різноманітних корисностей насаджень). Тому системний підхід до вирішення проблеми підвищення продуктивності лісів дасть змогу надати об'єктивну оцінку їхньої фактичної продуктивності та визначити найдієвіше заходи з її покращення. Основою підвищення продуктивності лісів має стати диференціація систем ведення лісового господарства та окремих лісогосподарських заходів на зональнотипологічній основі.

Під час визначення обсягів та черговості вжиття відповідних лісогосподарських заходів доцільно використовувати дані продуктивності модальних та еталонних корінних деревостанів. Сучасний стан, поширення, продуктивність дубових насаджень в межах Лівобережного Лісостепу України та використання ними лісорослинного потенціалу свого часу вивчали I. В. Туркевич [12], М. М. Ведмідь та В. А. Гаврилов $[14,13]$, Р. В. Головач
[2], Л. С. Луначевський [5, 6], В. В. Назаренко та В. П. Пастернак [8], В. П. Ткач [11], М. Г. Румянцев та О. В. Кобець [10] й інші.

Проте недостатньо вичерпними є дані щодо сучасного стану дубових насаджень, їхньої продуктивності та використання ними лісорослинного потенціалу в лісовому фонді ДП "Жовтневе ЛГ", розташованому в межах лісостепової частини Харківської області. Зважаючи на те, що майже всі ліси підприємства належать до категорії "рекреаційно-оздоровчі ліси" i незначна їх частка - до категорії "захисні ліси", вони є цінним об'єктом для вивчення. Все зазначене й зумовлює актуальність і важливість проведення наукових досліджень стану цих лісів.

Матеріали та методи дослідження. Основою для виконання розрахунків були матеріали ВО "Укрдержліспроект". Загалом проаналізували понад 6 тис. таксаційних виділів дубових насаджень різного походження в межах ДП "Жовтневе ЛГ" (станом на 2017 р.), що є типовими для умов лісостепової частини Харківської області. Площа досліджуваних насаджень становила майже 34 тис. га.

Таксаційні показники дубових насаджень встановлювали за десятирічними класами віку. Кількісне оцінювання ефективності ВЛП дубовими насадженнями проведено шляхом порівняння продуктивності модальних і еталонних (високопродуктивних) насаджень $[6,7$, $9,10,11]$ у найпоширенішому типі лісу - свіжа кленово-липова діброва. До еталонних (високопродуктивних) дубових насаджень відносили ділянки високоповнотних (відносна повнота 0,8 і вище) і високобонітетних (клас бонітету I і вище) насаджень відповідних класів віку із участю дуба у складі насаджень 7 одиниць і більше. Різниця між продуктивністю модальних і еталонних (високопродуктивних) насаджень вказує на резерв підвищення загальної продуктивності дубових лісів регіону досліджень. Цей метод дає змогу виявити динамічні тенденції природної та штучної змін порід, вибрати заходи із запобігання небажаним змінам у панівних типах лісу.

\section{Результати дослідження та їх обговорення / Research results and their discussion}

Результати проведених досліджень свідчать, що серед загальної площі вкритих лісовою рослинністю ділянок ДП "Жовтневе ЛГ" (45,3 тис. га) найбільшу частку займають дубові насадження - 74,8 \% (33,9 тис. га). Друге місце за площею посідають соснові насадження 16,7 \% (майже 7,6 тис. га), далі насадження за участю клена гостролистого - 1,5 \% (майже 0,7 тис. га). Решта порід займають значно меншу площу (табл. 1).

Табл. 1. Розподіл площі і запасу вкритих лісовою рослинністю ділянок ДП "Жовтневе ЛГ" за панівними породами / The distribution by prevailing species of the area and stock of the lands covered by forest vegetation in the Zhovtneve Forestry State Enterprise

\begin{tabular}{|c|c|c|c|c|c|}
\hline \multirow{2}{*}{ Панівна порода } & \multicolumn{2}{|c|}{ Площа } & \multicolumn{3}{|c|}{ Запас } \\
\cline { 2 - 6 } & га & $\%$ & тис. $^{3}$ & $\%$ & на 1 га, м \\
\hline Дуб звичайний & 33896,8 & 74,8 & 7867,84 & 71,2 & 232 \\
\hline Сосна звичайна & 7571,0 & 16,7 & 2404,21 & 21,8 & 318 \\
\hline Клен гостролистий & 676,6 & 1,5 & 120,54 & 1,1 & 178 \\
\hline Інші породи & 3177,4 & 7,0 & 652,94 & 5,9 & 205 \\
\hline Разом & 45321,8 & 100 & 11045,53 & 100 & 244 \\
\hline
\end{tabular}

Scientific Bulletin of UNFU, 2021, vol. 31, no 5 
Серед загальної площі дубових лісів ДП "Жовтневе ЛГ" (33897 га) як за площею, так і за запасом істотно переважають насадження порослевого походження, частка яких сягає 69,7 \% - за площею та 72,8 \% - за запасом. Частка дубняків штучного походження за площею становить 27,5 \% (9308,5 га) і за запасом - 24,0 \% $\left(1890,4\right.$ тис. $\left.\mathbf{m}^{3}\right)$ від загальної площі дубових лісів.

Табл. 2. Розподіл площі та запасу дубових насаджень ДП "Жовтневе ЛГ" за їхнім походженням / The distribution of the area and stock of oak plantations by their origin in the Zhovtneve Forestry State Enterprise

\begin{tabular}{|c|c|c|c|c|c|}
\hline Походження дубо- & \multicolumn{2}{|c|}{ Площа } & \multicolumn{3}{|c|}{ Запас } \\
\cline { 2 - 6 } вих насаджень & га & $\%$ & тис. м $^{3}$ & $\%$ & на 1 га, м \\
\hline Порослеве & 23638,8 & 69,7 & 5726,0 & 72,8 & 242 \\
\hline Насіннєве природне & 949,5 & 2,8 & 251,4 & 3,2 & 265 \\
\hline Насіннєве штучне & 9308,5 & 27,5 & 1890,4 & 24,0 & 203 \\
\hline Разом & 33896,8 & 100 & 7867,8 & 100 & 232 \\
\hline
\end{tabular}

Дубові насадження насіннєвого природного походження ростуть на невеликій площі - тільки на 949,5 га (табл. 2) та під час подальших розрахунків вони були об'єднані із групою порослевих дубових насаджень. Найпродуктивнішими виявилися насадження насіннєвого природного походження, запас яких сягає 265 $\mathrm{M}^{3} \cdot \mathrm{ra}^{-1}$. Менш продуктивними $€$ порослеві насадження $\left(242 \mathrm{~m}^{3} \cdot \mathrm{ra}^{-1}\right)$, а найменший запас мають дубові насадження насіннєвого штучного походження $-203 \mathrm{~m}^{3} \cdot \mathrm{ra}^{-1}$.

Дубові насадження ДП "Жовтневе ЛГ" загалом ростуть у 9 типах лісу, а найбільша їхня площа зосереджена в умовах свіжої кленово-липової діброви - 30426,7 га, або 89,8 \% від загальної площі дубових лісів та в умовах сухої кленово-липової діброви - 2554,6 га, або $7,5 \%$. Частка інших типів лісу представлена дубняками на площі 915,5 га, або тільки на 2,7 \% (табл. 3). На площі 37,9 га дубняки ростуть в умовах свіжого дубовососнового субору і представлені в цих умовах похідними деревостанами. Одним із шляхів підвищення продуктивності насаджень підприємства $є$ заміна таких насаджень на корінні соснові деревостани, а в перспективі - створення лісових культур у відповідних типах лісу.

Табл. 3. Розподіл площі дубових насаджень ДП "Жовтневе ЛГ" за типами лісу /

The distribution of the area of oak plantations by forest types in the the Zhovtneve Forestry State Enterprise

\begin{tabular}{|c|c|c|c|c|c|c|c|}
\hline \multicolumn{2}{|l|}{ Тип лісу } & \multicolumn{2}{|c|}{ Площа } & \multicolumn{3}{|c|}{ Запас } & \multirow{2}{*}{$\begin{array}{c}\text { Сер. вік, } \\
\text { років }\end{array}$} \\
\hline назва & індекс & га & $\%$ & тис. $\mathrm{m}^{3}$ & $\%$ & на 1 га, м ${ }^{3}$ & \\
\hline Свіжий дубово-сосновий субір & $\mathrm{B}_{2}$-дC & 37,9 & 0,1 & 7,7 & 0,1 & 203 & 76 \\
\hline Суха кленово-липова діброва & $\mathrm{D}_{1}$-клД & 2554,6 & 7,5 & 461,7 & 5,9 & 181 & 62 \\
\hline Свіжа кленово-липова діброва & $\mathrm{D}_{2}$-клД & 30426,7 & 89,8 & 7189,9 & 91,4 & 236 & 69 \\
\hline Волога кленово-липова діброва & $\mathrm{D}_{3}$-клД & 48,9 & 0,1 & 13 & 0,2 & 266 & 73 \\
\hline Волога ясенево-липова діброва & $\mathrm{D}_{3}$-ялД & 49,5 & 0,1 & 13,7 & 0,2 & 277 & 74 \\
\hline Суха еродована кленова судіброва & $\mathrm{C}_{1}$-єкД & 60,4 & 0,2 & 6,4 & 0,1 & 106 & 52 \\
\hline Свіжий липово-дубово-сосновий сугрудок & $\mathrm{C}_{2}$-лдС & 656,4 & 2,0 & 160,9 & 1,9 & 245 & 65 \\
\hline Волога кленово-липова судіброва & $\mathrm{C}_{3}$-клД & 21,3 & 0,1 & 4,1 & 0,1 & 192 & 69 \\
\hline Вологий липово-дубово-сосновий сугрудок & $\mathrm{C}_{3}$-лдС & 41,1 & 0,1 & 10,4 & 0,1 & 253 & 70 \\
\hline \multicolumn{2}{|l|}{ Разом } & 33896,8 & 100 & 7867,8 & 100 & 232 & 68 \\
\hline
\end{tabular}

Вікова структура дубових насаджень $є$ розбалансованою $з$ істотними переважанням за площею середньовікових насаджень, частка яких сягає 77,8 \% (19128,9 га) у насадженнях природного походження та 85,8 \% (7989,5 га) - штучного походження (табл. 4).

Табл. 4. Розподіл площі дубових насаджень ДП "Жовтневе ЛГ" за групами віку в розрізі походження / The distribution of the area of oak plantations by age groups in terms of origin (in the numerator - for oak plantations of natural origin; in the denominator - for oak plantations of artificial origin)in the Zhovtneve Forestry State Enterprise

\begin{tabular}{|c|c|c|c|c|c|}
\hline \multirow{2}{*}{\begin{tabular}{|c} 
Група віку дубових \\
насаджень \\
\end{tabular}} & \multicolumn{2}{|c|}{ Площа } & \multicolumn{3}{|c|}{ Запас } \\
\hline & га & $\%$ & тис. ${ }^{3}$ & $\%$ & на 1 га, м $^{3}$ \\
\hline \multirow{2}{*}{ Молодняки } & 67,7 & $\underline{0,3}$ & 10,3 & $\underline{0,2}$ & 152 \\
\hline & 1315,4 & $\overline{14,1}$ & $\overline{74,3}$ & $\overline{3,9}$ & 56 \\
\hline \multirow{2}{*}{ Середньовікові } & 19128,9 & 77,8 & 4811,1 & $\underline{80,5}$ & 252 \\
\hline & $\overline{7989,5}$ & $\overline{85,8}$ & $\overline{1815,7}$ & 96 & $\overline{227}$ \\
\hline \multirow{2}{*}{ Пристиглі } & $\underline{2665,1}$ & $\underline{10,8}$ & $\underline{570,8}$ & $\underline{9,5}$ & $\underline{214}$ \\
\hline & - & - & - & - & - \\
\hline \multirow{2}{*}{ Стиглі та перестійні } & $\underline{2726,6}$ & $\underline{11,1}$ & $\underline{585,3}$ & $\underline{9,8}$ & $\underline{215}$ \\
\hline & 3,6 & 0,1 & 0,4 & 0,1 & 111 \\
\hline \multirow{2}{*}{ Разом } & $\underline{24588,3}$ & $\underline{100}$ & $\underline{5977,4}$ & $\underline{100}$ & $\underline{243}$ \\
\hline & 9308,5 & 100 & 1890,4 & 100 & 203 \\
\hline
\end{tabular}

Примітка: у чисельнику - для дубових насаджень природного походження; у знаменнику - для дубових насаджень штучного походження.

Серед природних дубняків частка молодняків становить $0,3 \%$ (67,7 га), пристиглих насаджень - 10,8\% (2665,1 га), стиглих і перестійних - 11,1\% (2726,6 га). Частка дубових молодняків штучного походження є дещо вищою $(14,1 \%, 1315,4$ га), що пов'язано із особли- востями ведення лісового господарства в дубових лісах підприємства. Серед показників продуктивності лісів виділяють клас бонітету та повноту насаджень. У дубових лісах ДП "Жовтневе ЛГ" виявлено істотне переважання за площею насаджень природного походження II класу бонітету, частка яких становить 62,4 (15336,0 га) та насаджень штучного походження I і вище класів бонітету 49,5 \% (40606,5 га), що загалом свідчить про сприятливі умови для вирощування дубових насаджень, що виконуватимуть важливі еколого-захисні, санітарно-оздоровчі та рекреаційні функції (табл. 5).

Табл. 5. Розподіл площі дубових насаджень ДП "Жовтневе ЛГ" за класами бонітету в розрізі походження / The distribution of the area of oak plantations by classes of quality in terms of origin (in the numerator - for oak plantations of natural origin; in the denominator - for oak plantations of artificial origin)in the Zhovtneve Forestry State Enterprise

\begin{tabular}{|c|c|c|c|c|c|}
\hline \multirow{2}{*}{$\begin{array}{c}\text { Клас бонітету } \\
\text { дубових насаджень }\end{array}$} & \multicolumn{2}{|c|}{ Площа } & \multicolumn{3}{|c|}{ Запас } \\
\hline & га & $\%$ & тис. $\mathrm{m}^{3}$ & $\%$ & на 1 га, м $^{3}$ \\
\hline \multirow{2}{*}{ I і вище } & 1476,3 & 6,0 & 443,0 & 7,4 & 300 \\
\hline & $\overline{4606,5}$ & 49,5 & 1048,9 & 55 & 228 \\
\hline \multirow{2}{*}{ II } & 15336,0 & 62,4 & 3962,0 & 66,3 & 258 \\
\hline & 3560,5 & 38,2 & 687,5 & 36,4 & 193 \\
\hline \multirow{2}{*}{ III } & 7207,3 & 29,3 & 1488,8 & 24,9 & 207 \\
\hline & 983,0 & $\overline{10,6}$ & $\overline{140,7}$ & 7,4 & 143 \\
\hline \multirow{2}{*}{ IV і нижче } & 568,7 & 2,3 & 83,6 & 1,4 & 147 \\
\hline & $\overline{158,5}$ & $\overline{1,7}$ & $\overline{13,3}$ & $\overline{0,7}$ & 84 \\
\hline \multirow{2}{*}{ Разом } & 24588,3 & 100 & $\underline{5977,4}$ & $\underline{100}$ & 243 \\
\hline & 9308,5 & 100 & $\overline{1890,4}$ & 100 & 203 \\
\hline
\end{tabular}

Примітка: у чисельнику - для дубових насаджень природного походження; у знаменнику - для дубових насаджень штучного походження. 
Частка дубняків IV і нижче класів бонітету є незначною та становить 2,3 \% (568,7 га) і 1,7\% (158,5 га) від площі дубових насаджень природного і штучного походження відповідно. Загалом дубові насадження підприємства мають доволі високу повноту. Так, серед загальної площі переважають насадження із повнотою 0,7, що займають 47,1 (11586,5 га) та 42,5 \% (3945,7 га) площі дубняків природного і штучного походження відповідно (табл. 6).

Табл. 6. Розподіл площі дубових насаджень ДП "Жовтневе ЛГ" за повнотами в розрізі походження / The distribution of the area of oak plantations by completeness in terms of origin (in the numerator - for oak plantations of natural origin; in the denominator - for oak plantations of artificial origin)in the Zhovtneve Forestry State Enterprise

\begin{tabular}{|c|c|c|c|c|c|}
\hline \multirow{2}{*}{$\begin{array}{c}\text { Повнота дубових } \\
\text { насаджень }\end{array}$} & \multicolumn{2}{|c|}{ Площа } & \multicolumn{3}{|c|}{ Запас } \\
\hline & га & $\%$ & тис. $\mathrm{M}^{3}$ & $\%$ & на 1 га, м $^{3}$ \\
\hline \multirow{2}{*}{ 0,4 і нижче } & 329,0 & $\underline{1,3}$ & 48,1 & $\underline{0,8}$ & $\underline{146}$ \\
\hline & 13,7 & $\overline{0,1}$ & 0,7 & - & 51 \\
\hline \multirow{2}{*}{0,5} & 1248,8 & 5,1 & 235,2 & 3,9 & 188 \\
\hline & 165,9 & 1,8 & 13,6 & 0,7 & 82 \\
\hline \multirow{2}{*}{0,6} & 7453,2 & 30,3 & 1668,7 & 27,9 & 224 \\
\hline & 728,8 & 7,8 & 118,7 & 6,3 & 163 \\
\hline \multirow{2}{*}{0,7} & 11586,5 & 47,1 & 2918,2 & 48,8 & 252 \\
\hline & $\overline{3945,7}$ & $\overline{42,5}$ & 782,4 & $\overline{41,4}$ & $\overline{198}$ \\
\hline \multirow{2}{*}{0,8} & 3680,9 & 15,0 & 1018,1 & $\underline{17,0}$ & 277 \\
\hline & $\overline{3837,4}$ & $\overline{41,2}$ & 847,3 & 44,8 & $\overline{221}$ \\
\hline \multirow{2}{*}{ 0,9 і вище } & 289,9 & $\underline{1,2}$ & $\underline{89,1}$ & $\underline{1,5}$ & $\underline{307}$ \\
\hline & $\overline{617,0}$ & $\overline{6,6}$ & $\overline{127,7}$ & $\overline{6,8}$ & $\overline{207}$ \\
\hline \multirow{2}{*}{ Разом } & 24588,3 & 100 & $\underline{5977,4}$ & 100 & 243 \\
\hline & $\overline{9308,5}$ & $\overline{100}$ & $\overline{1890,4}$ & $\overline{100}$ & $\overline{203}$ \\
\hline
\end{tabular}

Примітка: у чисельнику - для дубових насаджень природного походження; у знаменнику - для дубових насаджень штучного походження.
Доволі значною $є$ частка дубових насаджень штучного походження повнотою 0,8 (41,2 \%, 3837,4 га) і дубових насаджень природного походження повнотою 0,6 $(30,3 \%, 7453,2$ га). Результати аналізу динаміки основних таксаційних показників дубових насаджень (табл. 7) в розрізі класів віку (середній вік, середній діаметр, середня висота, частка дуба в складі насаджень, повнота, площа, запас на 1 га, загальний запас) свідчить про розбалансованість вікової структури із істотним переважанням за площею насаджень природного походження VII-X класів віку, частка площі яких становить 81,7 \% та насаджень штучного походження V-VIII класів віку із часткою 83,2 \% від загальної площі дубових лісів відповідного походження.

Для дубових лісостанів природного походження характерні такі середні таксаційні показники: середній вік - 84 роки; середній діаметр - 30,9 см; середня висота 22,9 м; участь дуба у складі насаджень - 8,1 од.; середня повнота - 0,66; середній запас на 1 га - 243 м ${ }^{3}$. Дубові насадження штучного походження мають такі середні таксаційні показники: середній вік - 54 роки; середній діаметр - 19,9 см; середня висота - 17,0 м; участь дуба в складі насаджень - 7,3 од.; середня повнота 0,73 ; середній запас на 1 га $-203 \mathrm{~m}^{3}$.

Аналіз продуктивності дубових насаджень проведено шляхом зіставлення запасів на 1 га модальних дубових насаджень із відповідними значеннями показників місцевих високопродуктивних (еталонних) насаджень, відібраних за матеріалами лісовпорядкування. Значення запасів модальних насаджень природного і штучного походження, а також високопродуктивних насаджень ДП "Жовтневе ЛГ" (тип лісу - $\mathrm{D}_{2}$-клД) наведено в табл. 8.

Табл. 7. Динаміка середніх таксаційних показників дубових насаджень ДП "Жовтневе ЛГ" з віком у розрізі походження /

The dynamics of average tax indicators of oak plantations with age in terms of origin (in the numerator - for oak plantations of natural origin; in the denominator - for oak plantations of artificial origin) in the Zhovtneve Forestry State Enterprise

\begin{tabular}{|c|c|c|c|c|c|c|c|c|}
\hline \multirow{2}{*}{ Класи віку } & \multirow{2}{*}{ Площа, га } & \multicolumn{2}{|c|}{ Запас } & \multicolumn{5}{|c|}{ Середні таксаційні показники дубових насаджень } \\
\hline & & тис. $\mathrm{m}^{3}$ & на 1 га, м $^{3}$ & вік, років & діаметр, см & висота, м & участь в складі, од. & повнота \\
\hline I & $4 \overline{\overline{3}}, 0$ & $\overline{\bar{z}}$ & $\overline{\overline{5}}$ & $\overline{\overline{8}}$ & $\overline{\overline{1,6}}$ & $\overline{\overline{2}} \overline{0}$ & $\overline{\overline{9,0}}$ & $0, \overline{\overline{7}} 2$ \\
\hline \multirow{2}{*}{ II } & $\underline{4,5}$ & $\underline{0,1}$ & $\underline{22}$ & $\underline{16}$ & $\underline{7,9}$ & $\underline{5,1}$ & $\underline{3,3}$ & $\underline{0,67}$ \\
\hline & 185,7 & 5,2 & $\frac{28}{28}$ & $\frac{i}{14}$ & 6,1 & 4,8 & 7,1 & 0,75 \\
\hline \multirow{2}{*}{ III } & $\underline{38,0}$ & $\underline{5,1}$ & $\underline{134}$ & $\underline{26}$ & $\underline{19,5}$ & $\underline{12,5}$ & $\underline{5,1}$ & $\underline{0,71}$ \\
\hline & 222,3 & 20,5 & 92 & $\overline{27}$ & 11,9 & 9,2 & 5,9 & 0,73 \\
\hline \multirow{2}{*}{ IV } & $\underline{81,4}$ & 10,9 & 134 & 37 & 19 & 15,5 & 5,3 & 0,72 \\
\hline & $\overline{510,7}$ & 48,1 & 94 & 36 & $\overline{14,4}$ & 11,8 & 5,7 & 0,72 \\
\hline \multirow{2}{*}{ V } & 355,3 & 62,7 & 176 & 47 & 20 & 17,4 & 6,1 & 0,70 \\
\hline & 2398,5 & $\overline{418,9}$ & $\overline{175}$ & $\overline{47}$ & 18,4 & 15,9 & 6,6 & $\overline{0,74}$ \\
\hline \multirow{2}{*}{ VI } & 1038,0 & 206,6 & 199 & $\underline{58}$ & 23,5 & 19,7 & 6,6 & $\underline{0,70}$ \\
\hline & 1939,0 & 418,4 & 216 & $\frac{\overline{56}}{56}$ & 21,3 & $\overline{18,4}$ & $\overline{6,8}$ & $\overline{0,74}$ \\
\hline \multirow{2}{*}{ VII } & 3397,1 & 738,9 & 218 & 68 & 25,9 & 21,1 & 7,6 & 0,69 \\
\hline & 1886,2 & 481,4 & 255 & $\frac{67}{67}$ & 24,4 & $\overline{20,4}$ & $\overline{7,8}$ & $\overline{0,73}$ \\
\hline \multirow{2}{*}{ VIII } & 3279,3 & 793,7 & 242 & 77 & 29,1 & 22,6 & 8,3 & 0,68 \\
\hline & 1519,1 & 442,0 & 291 & 76 & 26,5 & 22,7 & 8,5 & 0,73 \\
\hline \multirow[b]{2}{*}{ IX } & 7605,3 & 1888,0 & 248 & 87 & 32 & 23,5 & 8,5 & 0,66 \\
\hline & 155,7 & 46,1 & 296 & 85 & 31,0 & 23,8 & 9,0 & 0,70 \\
\hline \multirow[b]{2}{*}{$\mathrm{X}$} & $\underline{5833,5}$ & 1451,0 & 249 & 96 & 34,7 & 24,3 & 8,5 & 0,64 \\
\hline & 11,5 & 3,4 & 281 & 97 & 35,7 & 25,4 & 8,4 & 0,63 \\
\hline \multirow{2}{*}{ XI } & 1405,5 & 376,0 & 268 & 107 & 37,4 & 25,7 & 8,3 & 0,63 \\
\hline & 16,8 & 4,1 & $\overline{264}$ & 108 & 33,2 & 25,7 & 9,8 & 0,60 \\
\hline \multirow{2}{*}{ XII } & $\underline{1067,7}$ & $\underline{301,3}$ & 282 & 117 & 41,4 & 26,6 & 8,9 & $\underline{0,61}$ \\
\hline & - & - & - & - & - & - & - & - \\
\hline \multirow{2}{*}{ XIII i > } & $\underline{482,7}$ & 143,2 & 297 & 128 & $\underline{42}$ & 27,6 & $\underline{8,7}$ & $\underline{0,58}$ \\
\hline & - & - & - & - & - & - & - & - \\
\hline \multirow{2}{*}{ Разом } & 24588,3 & $\underline{5977,4}$ & 243 & $\underline{84}$ & 30,9 & 22,9 & $\underline{8,1}$ & $\underline{0,66}$ \\
\hline & 9308,5 & 1890,4 & 203 & $\overline{54}$ & 19,9 & 17,0 & 7,3 & 0,73 \\
\hline
\end{tabular}

Примітка: у чисельнику - для дубових насаджень природного походження; у знаменнику - для дубових насаджень штучного походження. 
Табл. 8. Динаміка запасів $\left(\mathrm{m}^{3} \cdot \mathrm{ra}^{-1}\right)$ модальних насаджень природного і штучного походження, а також високопродуктивних насаджень ДП "Жовтневе ЛГ" / The dynamics of reserves $\left(\mathrm{m}^{3} \mathrm{ha}^{-1}\right)$ of modal plantations of natural and artificial origin, as well as highly productive plantations in the Zhovtneve Forestry State Enterprise

\begin{tabular}{|c|c|c|c|c|c|c|c|c|c|c|c|c|}
\hline \multirow{2}{*}{ Деревостан } & \multicolumn{10}{|c|}{ Вік дубових насаджень, років } \\
\cline { 2 - 32 } & 10 & 20 & 30 & 40 & 50 & 60 & 70 & 80 & 90 & 100 & 110 & 120 \\
\hline Модальні природні & - & 67 & 111 & 141 & 169 & 193 & 214 & 233 & 248 & 260 & 269 & 275 \\
\hline Модальні штучні & 8 & 34 & 72 & 117 & 166 & 213 & 253 & 282 & 294 & 251 & - \\
\hline Високопродуктивні & 32 & 94 & 154 & 210 & 261 & 307 & 348 & 382 & 408 & 427 & 437 & 438 \\
\hline
\end{tabular}

Результати порівняльного аналізу запасів на 1 га модальних природних насаджень ДП "Жовтневе ЛГ" із відповідними значеннями показників місцевих високопродуктивних (еталонних) насаджень, відібраних за матеріалами лісовпорядкування (див. рис. 1) свідчать, що в середньому модальні насадження поступаються високопродуктивним у віці 120 років на $37 \%$ (на 163 $\left.\mathrm{M}^{3} \cdot \mathrm{ra}^{-1}\right)$. Це пояснюють насамперед тим, що серед модальних переважають насадження порослевого походження, а серед еталонних - лісостани природного насіннєвого походження.

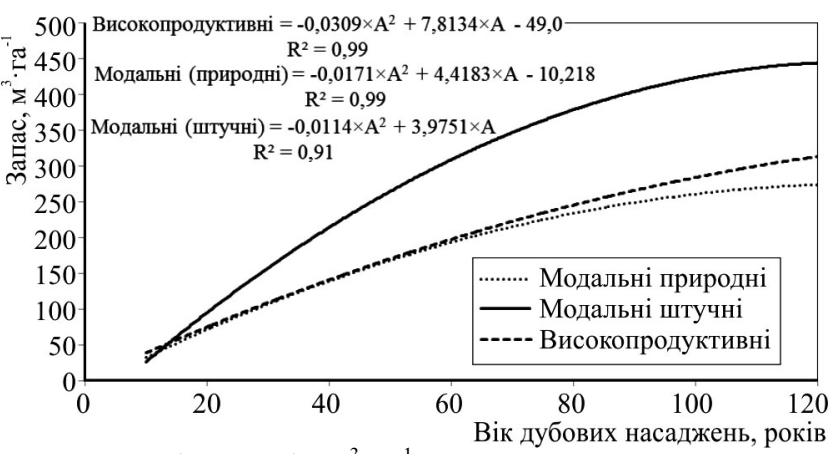

Рис. 1. Динаміка запасів $\left(\mathrm{m}^{3} \cdot \mathrm{ra}^{-1}\right)$ модальних насаджень природного і штучного походження, а також високопродуктивних насаджень ДП "Жовтневе ЛГ" / The dynamics of reserves $\left(\mathrm{m}^{3}\right.$ $\mathrm{ha}^{-1}$ ) of modal plantations of natural and artificial origin, as well as highly productive plantations in the Zhovtneve Forestry State Enterprise

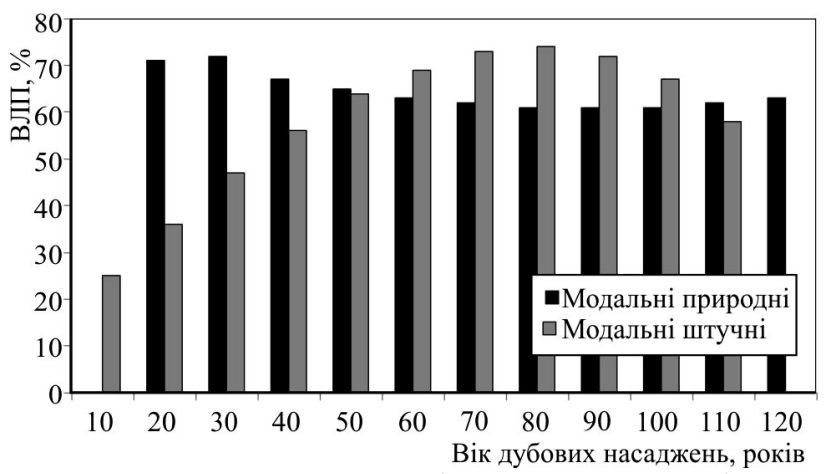

Рис. 2. Показники використання лісорослинного потенціалу модальними дубовими насадженнями природного і штучного походження порівняно із високопродуктивними (еталонними) насадженнями / Indicators of the use of forest vegetation potential by modal oak plantations of natural and artificial origin in comparison with highly productive (reference) plantations

Результати порівняльного аналізу запасів на 1 га модальних штучних насаджень ДП "Жовтневе ЛГ" із відповідними значеннями показників місцевих високопродуктивних (еталонних) насаджень свідчать, що в середньому модальні насадження поступаються високопродуктивним у віці 110 років на $42 \%$ (на $186 \mathrm{~m}^{3} \cdot \mathrm{ra}^{-1}$ ). Це пояснюють особливостями модальних штучних насаджень (зменшення запасу насаджень після 90-річного віку), тоді як у ролі еталонних насаджень виступають переважно насадження природного насіннєвого походження, запас яких збільшується й у віці 120 років.

Показники використання лісорослинного потенціалу (ВЛП) модальними дубняками природного походження порівняно із високопродуктивними насадженнями змінюються від $72 \%$ (у віці 30 років) до $61 \%$ (у віці 80100 років), а загалом середньозважене значення показника ВЛП становить $61 \%$ (рис. 2). Внаслідок недостатньо високих значень показників ВЛП модальними дубовими насадженнями природного походження втрати деревини підприємством сягають 3821,6 тис. м ${ }^{3}$ порівняно із високопродуктивними насадженнями.

Показники використання лісорослинного потенціалу (ВЛП) модальними дубняками штучного походження порівняно із високопродуктивними насадженнями змінюються від $25 \%$ (у віці 10 років) до $74 \%$ (у віці 80 років), а загалом середньозважене значення показника ВЛП становить $65 \%$. Внаслідок недостатньо високих значень показників ВЛП модальними дубовими насадженнями штучного походження втрати деревини підприємством сягають 1017,9 тис. м³ порівняно із високопродуктивними насадженнями.

Обговорення результатів дослідження. Стан і продуктивність дубових насаджень і використання ними лісорослинного потенціалу в межах Лівобережного Лісостепу України було предметом вивчення багатьох науковців $[2,5,6,8,10,11,12,13,14]$. За результатами їх досліджень визначено показники ВЛП дубовими насадженнями за панівними типами лісу в межах лісогосподарських округів і запропоновано заходи 3 підвищення продуктивності таких лісів. Ці заходи полягали у заміні малоцінних молодняків і похідних деревостанів шляхом проведення реконструктивних рубань; переформуванні простих одновікових насаджень у мішані за складом і складні за будовою різновікові насадження; максимальному використанні попереднього поновлення господарсько цінних порід, своєчасному проведенні доглядових рубань; ефективному захисті лісів від шкідників, хвороб і пожеж; збільшенні обсягів вибіркових і поступових рубок головного користування та лісовідновних рубок; веденні лісового господарства на типологічній основі.

Аналіз наших досліджень показав, що на підприємстві загалом $є$ великий резерв підвищення продуктивності корінних деревостанів у відповідних типах лісу шляхом розроблення та впровадження у лісогосподарське виробництво відповідних заходів.

\section{Висновок / Conclusions}

У лісостеповій частині Харківської області в лісовому фонді ДП "Жовтневе ЛГ" найпоширенішими є дубові лісостани, частка яких становить 74,8 \% (33,9 тис. га) від загальної площі вкритих лісовою рослинністю ділянок. Серед дубових лісів за площею істотно переважають високопродуктивні природні лісостани (62,4 \%) II класу бонітету та штучні насадження I і вище класу бонітету (49,5 \%) і мають повноту 0,7 та 0,8 , частка яких становить 62 і $84 \%$ відповідно. Проте в регіоні дослі- 
джень переважають порівняно низькопродуктивні порослеві дубняки. Ведення лісового господарства потрібно спрямувати на вирощування насаджень насіннєвого походження, які характеризуються більшим запасом порівняно із порослевими.

Вікова структура $є$ розбалансованою із переважанням за площею середньовікових насаджень, частка яких сягає $78 \%$ - у насадженнях природного походження та $86 \%$ - у насадженнях штучного походження.

Незважаючи на сприятливі лісорослинні умови Лісостепу Харківщини для успішного росту дубових насаджень, показники ефективності використання ними лісорослинного потенціалу є невисокими та змінюються у віці 80-100 років в межах 60-62 \% у насадженнях природного походження та 67-74 \% - у насадженнях штучного походження.

Оптимізація вікової структури та підвищення продуктивності дубових насаджень можливі завдяки своєчасному проведенню доглядових рубань та ширшому впровадженню у виробництво інших лісогосподарських заходів, спрямованих на відтворення дубових лісів природним насіннєвим або штучним шляхом.

\section{References}

1. Forest Fund Digest of Ukraine. (2012). Concluded by specialists of the production and technology department of the organisation "Ukrainian state forest project" ("Ukrderzhlisproekt") on the basis of state records of forests for 01.01.2011. Irpin: Ukrderzhlisproekt, $130 \mathrm{p}$. [In Ukrainian].

2. Holovach, R. V. (2008). Productivity of natural oak stands in a fresh maple-lime oakery of the Left-bank Forest Steppe. Forestry and Forest Melioration, 113, 137-141. [In Ukrainian].

3. Ivaniuk, I. D., \& Landin, V. P. (2019). Current condition and productivity of common oak stands (Quercus robur L.) in the forest fund of KP "Zhytomyroblagrolis". Agroecological Journal, 1, 23 28. https://doi.org/10.33730/2077-4893.1.2019.163243
4. Kopiy, L. I., Phizyk, I. V., Kopiy, S. L., Ahiy, V. O., \& Kopiy, M. L. (2015). Some distribution features and performance of oak forests of Transcarpathia. Scientific Bulletin of UNFU, 25(1), 69-74. [In Ukrainian].

5. Lunachevskyy, L. S. (2009). Productivity of artificial oak stands in the Left-bank Forest Steppe of Ukraine in the fresh maple-lime oak grove. Forestry and Forest Melioration, 115, 102-105. [In Ukrainian].

6. Lunachevskyy, L., \& Rumiantsev, M. (2020). Features of the growth of modal artificial oak stands of the Left-bank ForestSteppe zone and using the forest growth potential. Scientific Horizons, 03(88), 106-115. https://doi.org/10.33249/2663-2144-202088-3-106-115

7. Matusiak, M. V. (2019). The use of typological potential of major scales in Podillya region. Scientific Bulletin of UNFU, 29(2), 20 22. https://doi.org/10.15421/40290203

8. Nazarenko, V. V., \& Pasternak, V. P. (2016). Patterns of formation of forest types of Forest-steppe of the Kharkiv region. Kharkiv: KhNAU, 190 p. [In Ukrainian].

9. Ostapenko, B. F., \& Gerushinskiy, Z. Yu. (1975). Typological analysis of forests. Ecology, 4, 36-46. [In Russian].

10. Rumiantsev, M. N., \& Kobets, O. V. (2020). Mensuration indicators and productivity of oak stands in the Left-bank Forest-steppe zone of Ukraine. Forestry and Forest Melioration, 137, 9-15. https://doi.org/10.33220/1026-3365.137.2020.9

11. Tkach, V. P., Kobets, O. V., \& Rumiantsev, M. N. (2018). Use of forest site capacity by forests of Ukraine. Forestry and Forest Melioration, 132, 3-12. https://doi.org/10.33220/10263365.132.2018.3

12. Turkevych, I. V., Medvedev, L. A., Mokshanina, I. M., \& Lebedev, E. V. (1973). Methodological guidelines for determining the potential productivity of forest lands and the degree of their effective use. Kharkiv: URIFFM, 72 p. [In Russian].

13. Vedmid, M. M. (2005). To the issue of forest lands potential productivity evaluation. Forestry and Forest Melioration, 108, 3-8. [In Ukrainian].

14. Vedmid, M. M., \& Havrylov, V. A. (2004). Forest resources of the Left-bank Forest-Steppe of Ukraine and the use of lands potential productivity by forest stands. Forestry and Forest Melioration, 107, 14-19. [In Ukrainian].

S. I. Musienko, M. N. Rumiantsev, O. M. Tarnopilska, V. A. Lukyanets, V. V. Bondarenko

Ukrainian Research Institute of Forestry and Forest Melioration named after G. M. Vysotsky, Kharkiv, Ukraine

\section{SONDITION AND PRODUCTIVITY OF OAK PLANTATIONS IN THE FOREST-STEPPE OF KHARKIV REGION}

The paper presents some results of studying condition and productivity of oak plantations in the forest-steppe of Kharkiv region. In the course of research the current state of oak plantations of the Zhovtneve Forestry State Enterprise was analysed. The indicators of use of forest vegetation potential were determined in order to develop effective forestry measures aimed at increasing the productivity of oak forests in the region and strengthening their important ecological and protective functions. The authors used the materials of Ukrderzhlisproekt as the basis for the calculations. In total, more than 6,000 assessment sections of oak plantations of various origins were analysed within the Zhovtneve Forestry State Enterprise (as of 2017), which are typical for the conditions of the foreststeppe part of Kharkiv region. The area of the studied plantations was almost 34 thousand hectares. The results of the research show that among the total area of forested lands of the Zhovtneve Forestry State Enterprise (45.3 thousand hectares) the largest share is occupied by oak plantations - 74.8 \% (33.9 thousand hectares). Among the total area of oak forests of the Zhovtneve Forestry State Enterprise (33897 ha) both in terms of area and stock, plantations of undergrowth origin significantly predominate, their share reaches $69.7 \%$ by area and $72.8 \%$ by stock. Oak forests of natural origin are characterized by the following average taxonomic indicators: average age is 84 years; average diameter is $30.9 \mathrm{~cm}$; average height is $22.9 \mathrm{~m}$; participation of oak in plantations is 8.1 units; average completeness is 0.66 ; the average stock per 1 ha is $243 \mathrm{~m}^{3}$. Oak plantations of artificial origin have the following average tax rates: average age is 54 years; average diameter is $19.9 \mathrm{~cm}$; average height is $17.0 \mathrm{~m}$; participation of oak in plantations is 7.3 units; average completeness is 0.73 ; the average stock per 1 ha is $203 \mathrm{~m}^{3}$. Indicators of the use of forest vegetation potential by modal oak trees of artificial origin in comparison with highly productive plantations range from $25 \%$ (at the age of 10 years) to $74 \%$ (at the age of 80 years), and in general the weighted average indicator is $65 \%$. We have drawn the conclusion that optimization of the age structure and increase of productivity of oak plantations is possible due to timely felling of care and wider introduction into production of other forestry measures aimed at reproduction of oak forests by natural seeding or artificial means.

Keywords: forest vegetation potential; modal plantings; quality; type of forest. 